\title{
Correlation between Trees and Micro Climate on A Certified Green Building (Case Study in Wisma Subiyanto, Jakarta)
}

\author{
Eka Pradipta $^{1}$ \\ ${ }^{1}$ Department of Architecture, Faculty of Engineering, Universitas Indonesia
}

\begin{abstract}
Construction of buildings causes vegetation, trees, and soil to change into concrete (building) and asphalt (road) and impact on the increase of radiation heat in the surrounding environment. Trees absorb heat energy, can decrease the environmental temperature through shade canopy and evapotranspiration process. The process of reducing the temperature becomes a necessity in an urban area with a hot humid climate filled with buildings like the city of Jakarta. This paper discusses the results of research that aims to determine how effective the role of trees in lowering the ambient temperature around the building. The object of this study is a building that received a green certificate from GBCI in particular that received a high appraisal for the subcriteria of Appropriate Site Development / Site Landscaping and Heat Island Effect. The research was conducted using field temperature measurement method, simulation of calculation and heat visualization with Infrared Thermal Imaging tool. The analysis is done by comparing the measurement data, simulation, and visualization between several variables under study.
\end{abstract}

\section{Introduction}

Urban Heat Island is one of the impacts of reduced vegetation and trees that can lead to increased temperature in the microclimate of an urban land because the function of vegetation and trees is to provide shade, reduce solar radiation, modify microclimate, reduce relative humidity, decrease air temperature, reduce glare and control the wind [1]. Reducing the effects of Urban Heat Island (UHI) is one of the important things especially for energy conservation and heat reduction. Usually, the loss of vegetation and trees in urban areas is used for residence, factories, office buildings, warehouses, roads, pipes, power lines, railways, waterways, reservoirs, sewage and waste facilities, parks, cemeteries, and airports [2]. So it can be said that to reduce UHI effects, one way, can be done by arranging the architectural layout and landscape design to achieve the energy efficiency of the building and sustainable development [3].

Sustainable development began to be discussed in the last 3 decades, namely on the issue of assessing the environment. In his article entitled Changing Context For Environmental Knowledge, Cole explained that the development of the environment today is more directed to the context of responsibility and care, including building construction, judged by investigations with weighted exploration and performance indicators [4]. One of the building appraisal tools is Greenship which is a product of Green Building Council Indonesia (GBCI) which is an independent institution committed to environmental development practices that facilitate sustainable building.

There is some weighting in assessing a building. In Greenship, for new buildings, weights associated with vegetation and trees fall into the category of Appropriate Site Development (ASD) 5, Site Landscaping and 6, Micro Climate from the author's observations, have not included vegetation or tree relationships with temperature [5]. Whereas according to Idham 2016, in his book entitled Thermal Architecture and Comfort, mentioned that the temperature becomes an important aspect to consider in building a building in humid hot climate area, which is the author's research area and it is necessary to emphasize the orientation and determination of the direction of the building associated with the position at the latitude associated with the coming angle of the sun [6].

In addition the canopy/ crown of trees affect the reduction of solar radiation around the building [7]. The orientation and direction of the building, the many at least trees around the building, and the observation time, which is related to the sun's coming angle in a building becomes the main foundation of the researcher in conducting the research to find out the correlation between the trees and the decrease of ambient temperature around the building that obtained the green certificate from Greenship.

\section{Method}

Green building is environmentally responsible building, certified based on condition, natural character and regulation and standard that exist in a region. Regulations and standards on the condition and character of vegetation and trees in relation to environmental temperature have not been included in the category of assessments initiated by GBCI [5].

\footnotetext{
*Corresponding author: eka.pradipta@ui.ac.id
} 
This study wanted to know the relationship between vegetation and trees in green-certified buildings that meet the Appropriate Site Development (ASD) category in lowering the temperature in the surrounding environment,

1. Whether vegetation or trees around the building can lower the temperature of a green certified building in humid hot climates

2. Whether the tree spacing variable with the building, time and measurement side is related to the decrease in temperature around the building This research is a case study quantitative research that is [8],

1. Data collected in the form of an absolute value

2. It is generally done in engineering research

3. The result is more objective

This study uses a correlational approach where there are two or more variables involved in the research with an descriptive mode of writing, which is about the describe between the variables with each other by graphic, table, picture or and matrix [9].

In this study, we want to know about the temperature (heat, in degrees Celsius) released by the building and absorbed by the vegetation and trees (through shade and evapotranspiration). The study was conducted by comparing the environmental temperature (which is influenced by vegetation) from the building into the green category.

Table 1. Description about independent variable

\begin{tabular}{|l|l|l|}
\hline No & Independent variable & Description \\
\hline 1 & Side measured & $\begin{array}{l}\text { North, East, South, } \\
\text { West }\end{array}$ \\
\hline 2 & $\begin{array}{l}\text { Distance point of } \\
\text { measurement from wall (as } \\
\text { high as 1.5 m from ground) }\end{array}$ & 1,3 , and 6 meter \\
\hline 3 & Measurement time & $\begin{array}{l}10.00,11.00,12.00, \\
13.00, \text { and } 14.00 \text { local } \\
\text { time }\end{array}$ \\
\hline
\end{tabular}

Table 2. Description about independent variable

\begin{tabular}{|r|l|l|}
\hline No & Dependent variable & Description \\
\hline 1 & Temperature & Degree Celcius \\
\hline
\end{tabular}

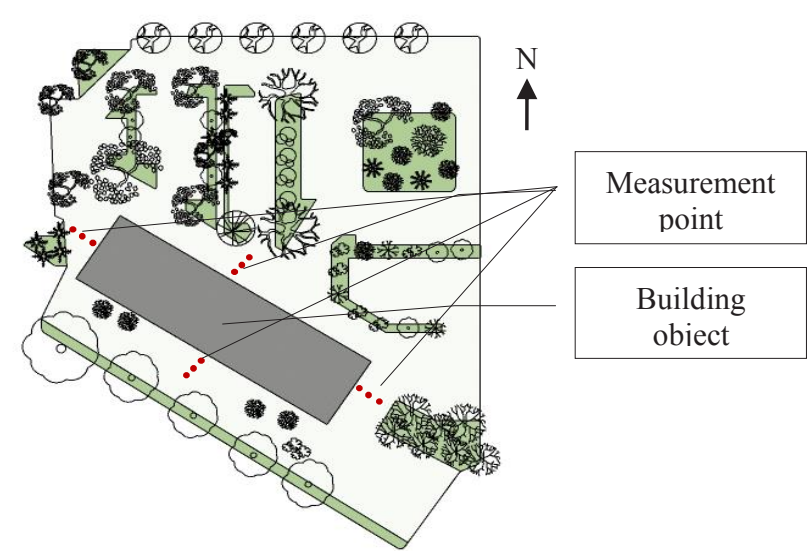

Fig. 1. Site research layout, consist of building, trees and measurement point.
Temperature measurements were performed using a Lutron LM8000A thermometer. Also embedded for additional data of moisture and wind speed at each measurement point. The wind factor also affects the temperature around the tree. In a hot and humid climate, the ideal situation is to have a tall tree canopy but no low plants can block the breeze [10]. The stagnant air created by the low trees and bushes will cause the heat.

To find out or map the last spread, measuring instrument Visual IR Thermometer Fluke VT04. The result of measurement is then done by using correlation measurement between variables to know the significance of variables using $99 \%$ confidence level. The analysis was performed using SPSS software.

\section{Results}

Tree canopy and vegetation can play an important role in reducing the effects of heat in open spaces by filtering incoming solar radiation before it reaches the soil surface. To do that trees filter the incoming heat (transmission less than that absorbed and reflected) by the leaf before it reaches the surface [11].

Measurements are carried out to determine the description or map of heat distribution. Fig. 4 is a side view of the measurements carried out in this study.

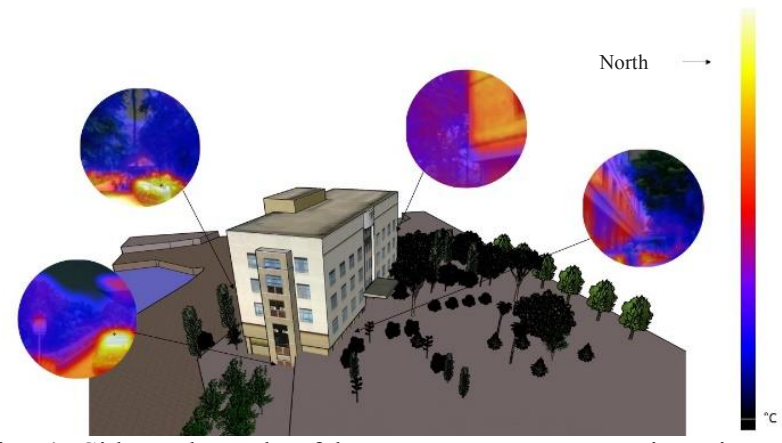

Fig. 4. Side and result of heat map measurement in Wisma Subiyanto building.

The result shown that a view of hot spreading map. From fig. 4 we know that the building reflect or emmit a heat while the surrounding that consist of trees was more cooler than it [10]. The trees was cooling the temperature by evapotranspiration and producing a shade to the site arround building [12].

The extent to which solar energy heats the urban environment is linked to surface albedo or reflectance of radiation. Less reflectance means that more energy is absorbed and stored, to warm the local environment. A lower urban albedo (commonly $15 \%$ versus a rural albedo of $20-25 \%$ ) results in relatively more absorption than in rural surroundings [13]. In figure 4 shows that less heat reflectances off buildings, parking lots and vehicles (looks hotter than others), so they stored it. Trees are cooler when compared to other elements of the building site.

The study also conducted by measuring the predefined independent variables. For the independent variables of the research can be known from the table 1 
and 2 and figure 1 . The analysis generate using descriptive statistic and continue with bivariate correlation.

Table 3. The descriptive analysis result

\begin{tabular}{|c|c|c|c|c|c|}
\hline & & & & & \\
\hline & $\mathrm{N}$ & Min & Max & Avrg. & Std. Dev \\
\hline $\begin{array}{l}\text { Combination } \\
\text { of distance } \\
\text { points }\end{array}$ & & & & & \\
\hline $\begin{array}{l}\text { Combination } \\
\text { of side } \\
\text { measurement }\end{array}$ & 60 & - & - & - & - \\
\hline $\begin{array}{l}\text { Combination } \\
\text { of time } \\
\text { measurement }\end{array}$ & & & & & \\
\hline $\begin{array}{l}\text { Temperature } \\
\text { results }\end{array}$ & & 33,0 & 43,0 & 35,64 & 1,8815 \\
\hline
\end{tabular}

Table 4. The correlation beetwen variables involved

\begin{tabular}{|c|c|c|c|c|}
\hline & $\begin{array}{l}\text { Combina } \\
\text { on } \\
\text { distance } \\
\text { points }\end{array}$ & $\begin{array}{l}\text { Combinati } \\
\text { men of side } \\
\text { ent }\end{array}$ & $\begin{array}{l}\text { Combinati } \\
\text { en of time } \\
\text { measurem } \\
\text { ent }\end{array}$ & $\begin{array}{l}\text { e } \\
\text { Temperat } \\
\text { ure results }\end{array}$ \\
\hline \begin{tabular}{l|l} 
Combinati & Pearson \\
on of Correlati \\
distance on
\end{tabular} & i 1 &, 000 &, 000 &,- 032 \\
\hline \begin{tabular}{l|l} 
points & $\begin{array}{l}\text { Sig. } \\
\text { tailed })\end{array}$
\end{tabular} & & 1,000 & 1,000 &, 810 \\
\hline $\mathrm{N}$ & 60 & 60 & 60 & 60 \\
\hline $\begin{array}{l}\text { Combinati Pearson } \\
\text { on of sideCorrelati } \\
\text { measurem on }\end{array}$ & $\mathrm{i}, 000$ & 1 &, 000 & ,097 \\
\hline ent \begin{tabular}{l|l} 
Sig. \\
tailed $)$
\end{tabular} & 1,000 & & 1,000 & ,462 \\
\hline $\mathrm{N}$ & 60 & 60 & 60 & 60 \\
\hline $\begin{array}{l}\text { Combinati } \\
\text { Pearson } \\
\text { on of time Correlati } \\
\text { measurem on }\end{array}$ & $\mathrm{i}, 000$ &, 000 & 1 &, $816^{* *}$ \\
\hline \begin{tabular}{|l} 
Sig. $\quad(2-$ \\
tailed)
\end{tabular} & 1,000 & 1,000 & &, 000 \\
\hline $\mathrm{N}$ & 60 & 60 & 60 & 60 \\
\hline $\begin{array}{c}\text { Temperatu } \begin{array}{l}\text { Pearson } \\
\text { re results u } \\
\text { Correlati } \\
\text { on }\end{array} \\
\text { on }\end{array}$ & i,- 032 & ,097 &, $816^{* *}$ & 1 \\
\hline $\begin{array}{l}\text { Sig. (2- } \\
\text { tailed) }\end{array}$ & 810 & ,462 &, 000 & \\
\hline $\mathrm{N}$ & 60 & 60 & 60 & 60 \\
\hline
\end{tabular}

From the results of measurement in the field obtained that information (table 4)

1. There is no significant correlation between the distance of trees 1-6 meter from the building in relation to the decrease in temperature. So, how close or far the tree from the building, no real effect on the temperature of the area.

2. There is no correlation between trees planted on a certain side of the building against a decrease in the temperature of the area between trees and buildings. From the eastern, western, northern, southernmost sides, it does not lower the temperature significantly.

3. The real correlation is in time to temperature (from 10:00 am to 2:00 pm) the more it gets hotter the temperature around
Table 3. Temperature/hours in various distance and side measurement from building wall $\left({ }^{\circ} \mathrm{C}\right)$

\begin{tabular}{|l|l|l|l|l|}
\hline $\begin{array}{l}\text { Average } \\
\text { temp/time }\left({ }^{\circ} \mathbf{C}\right)\end{array}$ & North & West & South & East \\
\hline $1 \mathrm{~m}$ & 35,5 & 36,6 & 35,96 & 34,9 \\
\hline $3 \mathrm{~m}$ & 35,62 & 35,6 & 35,92 & 35,2 \\
\hline $6 \mathrm{~m}$ & 35,5 & 35,94 & 35,78 & 35,16 \\
\hline Average & 35,54 & $\mathbf{3 6 , 0 6}$ & 35,89 & 35,06 \\
\hline
\end{tabular}

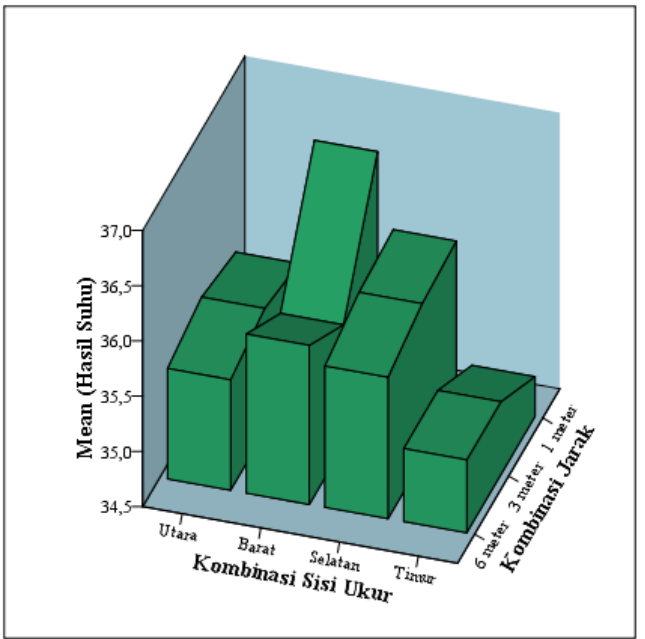

Fig 2. Temperature/hours in various distance and side measurement from building wall $\left({ }^{\circ} \mathrm{C}\right)$

From table 3 and fig. 2 it is found that the hottest side of the building, it is known that the measurement on the west of the building shows the highest temperature value when compared with the measurement on the other side..

From table 4 and fig. 3 it is found that the hottest point is that there is a distance of 1 meter from the building wall, which is expected to occur because of the heat reflectance of the wall material and the shade of trees that hold the sun's heat radiation, not to the point of measurement. Vegetation (trees) absorbs more radiation, rather than reflects it and also affects the microclimate through evapotranspiration [14].

Table 4. Temperature/hours in various orientation measurement from building $\left({ }^{\circ} \mathrm{C}\right)$

\begin{tabular}{|l|l|l|l|}
\hline Rata-rata suhu/sisi ukur $\left({ }^{\circ} \mathbf{C}\right)$ & $\mathbf{1 m}$ & $\mathbf{3 m}$ & $\mathbf{6 m}$ \\
\hline 10.00 & 33,43 & 33,40 & 33,33 \\
\hline 11.00 & 34,53 & 34,83 & 35,25 \\
\hline 12.00 & 35,43 & 35,80 & 35,73 \\
\hline 13.00 & 36,15 & 36,23 & 36,13 \\
\hline 14.00 & 39,18 & 37,63 & 37,55 \\
\hline Rata-rata & $\mathbf{3 5 , 7 4}$ & 35,58 & 35,60 \\
\hline
\end{tabular}




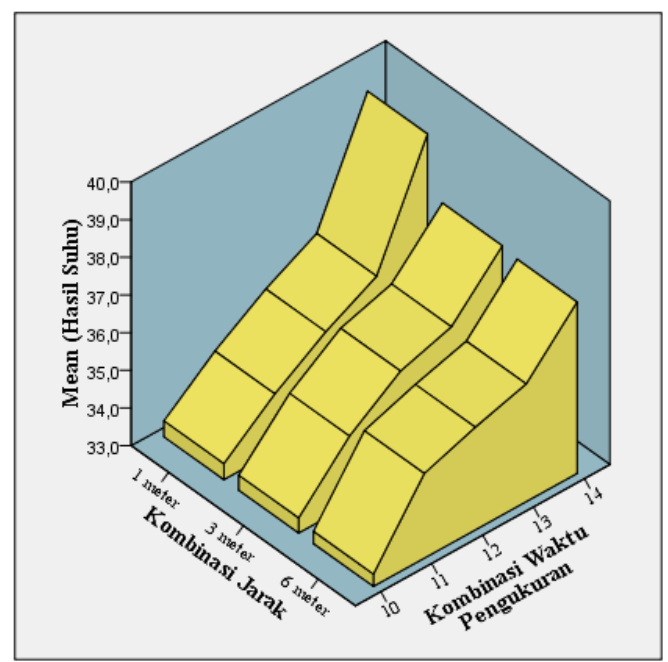

Fig 3. Graphic temperature/hours in various orientation measurement from building wall $\left({ }^{\circ} \mathrm{C}\right)$

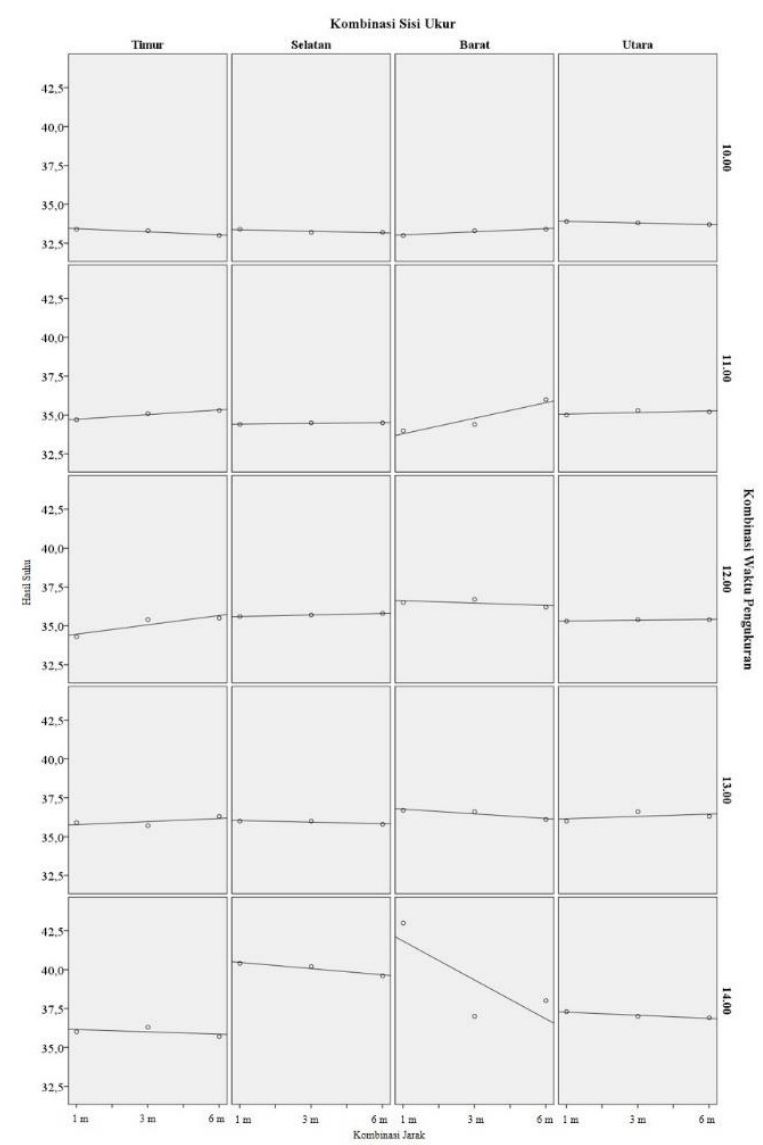

Fig 4. Graphic temperature/distance in various time and orientation measurement from building wall $\left({ }^{\circ} \mathrm{C}\right)$

\section{Discussion}

From the observation, it can be concluded that there is new method can be used as a new assessment method to determine the correlation of microclimate temperature around the building by knowing the relationship between trees, buildings and temperature in the other specific site of buildings. This will be very useful for the building manager, planner or related in the maintenance of green open space arround building.

From this research, we know that the hottest or the most cooling side area around the building (fig. 4). Also, we can predict the temperature as shown in figure 5. The linear regression used to analyse it. In Wisma Subiyanto building, in the west and south side, there have the decreasing temperature if we move far away from the building to the trees [12], while in the east the different data showed. It predicts because of the building store and emits the heat from morning sun radiation. Also the east side have more open side and more vehicle activities (car park, motorcycle and car pathways, etc.).

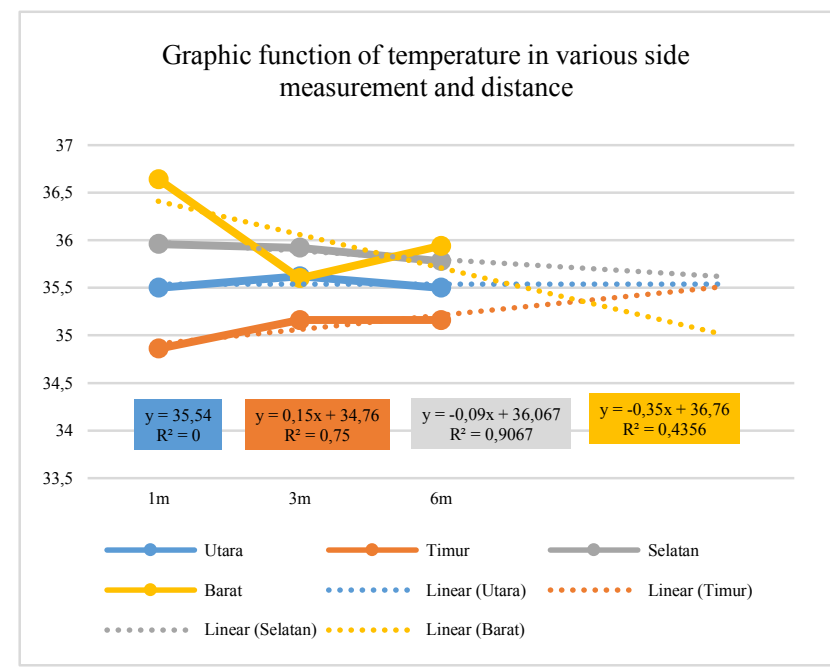

Fig 5 Graphic function of temperature in various side measurement and distance from building wall $\left({ }^{\circ} \mathrm{C}\right)$

In Northside we assumed that there's no different average of temperature in various distance because of most trees around that area is more much coverage than others. It predicted stabilised the temperature by tree's evapotranspiration and shading effects.

\section{Conclusion}

There is no significant difference for buildings in adding to environmental heat or trees in reducing the temperature of microclimate, especially in the distance between trees 1 - 6 meters around the building. On all sides of the building the tree is also not significantly different temperature, although, in this study, the highest average temperature is on the west side of the building with a distance of 1 meter from the wall of the building.

Further research is needed to find out the real effect of decreasing or rising temperatures caused by trees. In this study, only obtained predictions or trends relationship between trees, buildings and temperature 


\section{References}

[1] S. Roy, J. Byrne and C. Pickering, "A systematic quantitative review of urban tree benefits, costs, and assessment methods across cities in different climatic zones," Urban Forestry \& Urban Greening, 2012.

[2] McDonnell, "Ecosystem Structure and Function along Urban-Rural Gradients: An UnexploitedOpportunity for Ecology," Ecology, Vol. 7, pp. 1232-1237, 1990.

[3] B. Hong and B. Lin, "Numerical studies of the outdoor wind environment and thermal comfort at pedestrian level in housing blocks with different building layout patterns and trees arrangement," Renewable Energy, pp. 18-27, 2015.

[4] R. J. Cole, "Changing context for environmental knowledge," Building Research \& Information, p. 91109, 2004.

[5] Green Building Council Indonesia, "Green Building Council Indonesia," Green Building Council Indonesia, 2018. [Online]. Available: http://www.gbcindonesia.org/greenship/ratingtools/summary. [Accessed May 2018].

[6] N. C. Idham, Arsitektur dan Kenyamanan Termal, Yogyakarta: Penerbit Andi, 2016.

[7] G. M. Heisler, "Effects of Individual Trees on the Solar Radiation Climate of Small Buildings," Urban Ecology, 1985.

[8] Sukandarrumidi, Metodologi Penelitian, Yogyakarta: Gadjah Mada University Press, 2012.

[9] E. R. Tufte, Envisioning Information, Connecticut: Graphics Press, 1990.

[10] N. Lechner, Heating, Cooling, Lighting, New Jersey: John Wiley \& Sons, 2015.

[11] M. F. Shahidan, E. Salleh and K. Mustafa, "Effects of Tree Canopies on Solar Radiation Filtration In a Tropical Microclimatic Environment," in PLEA2007. The 24th Conference on Passive and Low Energy Architecture, 2007.

[12] H. Akbari, Cooling Our Communities: A Guidebook on Tree Planting and Light-Colored Surfacing, Lawrence Berkeley National Laboratory, 1992.

[13] K. Doick and T. Hutchings, "Air temperature regulation by urban trees and green infrastructure," Forestry Commission, Surrey, 2013.

[14] Xiao Ling Chen, "Remote sensing image-based analysis of the relationship between urban heat island and land use/cover changes," Remote Sensing of Environment, 2006. 